\title{
From the Music Learning Process to Its Effective Design
}

\author{
https://doi.org/10.3991/ijet.v16i21.24273 \\ Michele Della Ventura \\ Music Academy Studio Musica, Treviso, Italy \\ micheledellaventura.mdvegmail.com
}

\begin{abstract}
This research paper analysis the implications of the use of the Information and Communication Technologies (ICT) on learning music theory. Qualitative and quantitative research methods were used to collect data, including instructor interviews, learning environment observations, and student surveys. The results indicated that the implementation of ICT in the learning process provided students with the opportunity to find applicable solutions to many problems of their instrumental performances. Furthermore, the design and implementation of ICT led the teacher to move from a passive teaching approach to an active teaching approach and allowed students to become active students even in classroom activities.
\end{abstract}

Keywords—digital skill, ICT, learning process, music education

\section{$1 \quad$ Introduction}

New technologies offer opportunities to create learning environments that extend the possibilities of "old" (but still useful) technologies (books, blackboards, ...). They have many aspects that allow the creation of learning environments that are suitable for the specific needs of all major disciplinary sectors. In this context, the teaching of music is undergoing a transformation that involves a complex innovation of teaching practices.

Many new technologies are interactive and it is easier to create learning environments in which students can [1-3]: learn by doing; receive feedback and continually refine their understanding; build new knowledge.

The learning environments supported by technology allows students to: use their current knowledge to build new knowledge, and create links between their previous knowledge and their current academic activities [4]. All this implies that the teacher must help students learn with understanding rather than promoting the acquisition of concepts.

Learning can be enhanced by helping students become more aware of themselves as learners [5] who actively monitor their learning strategies and resources and assess their readiness for particular tests and performances. [6] Learning is also enhanced helping students to represent problems at higher levels of abstraction [7]: helping students represent their solution strategies at a more general level can help them in- 
crease the probability of positive learn and decrease the degree to which a previous solution strategy is used inappropriately (negative learn).

The debate on the relationship between education and technologies is one of those on which the attention of the community is particularly focused, as this is a strategic sector for the development of knowledge and therefore of society in general. Within this, the field of musical learning is more specific, in which the study of the opportunities offered by new technologies (and related problems) is not yet very thorough and is often based on research carried out with methods unscientific, made by people who are not experts in experimental methodologies, which are generally music education teachers.

This paper presents a case study referred to a pilot project developed in a Music High School. The project aimed to experimenting an integrated and innovative environment to "expand" the teaching and communication activities, and improve the effectiveness of the teaching action to stimulate cognitive processes to:

- promote the acquisition of operational, executive and analytical skills,

- overcome learning difficulties related to problems of understanding, processing and structuring information and knowledge.

In other words, the goals of the study were: on the one hand, to analyse the benefits of using ICT as a tool to support students in improving their skills on music theory; on the other hand, to analyse the improvement in the instrumental students' performances.

This paper is organized as follows.

Section 2 presents a brief introduction of the use of online resources in music education in the related researches. Section 3 describes the concept of "learning environment". This is followed by an analysis related to the formulation of musical learning objectives. Section 4 shows a case study that illustrate the effectiveness of the proposed method. Finally, in Section 5 the paper ends with concluding remarks.

\section{$2 \quad$ Literature review}

The development of new technologies has changed the way teachers and students work, learn and communicate: music education is no exception [8].

Despite the expansion of technologies related to the music field and their constant presence in and out of the classroom [9], the attention on understanding how these technologies can be used to improve students' learning process has not yet received the proper consideration. Alongside the improvement of hardware tools (computers, tablets, smartphones, video cameras, ...) and the enhancement of the internet connection, there was an explosion of online music resources.

A huge number of videos can be found online, for example on YouTube and most of them are actively incorporated into educational frameworks [10-12]: documentaries, video lessons, music videos and tutorials. However, the use of online videos by students, if not supported by other tools, simply transfers the limits of traditional transmissive teaching [13] (see paragraph 4). 
A similar problem is found in websites dedicated to music, such as the weblog (a web page where texts, images, sounds, videos and links are published [14-16]) and the web forum (a discussion-based website with a comment system and publication of topics by subscribing readers). In the first case there are spaces dedicated to a specific composer or compositional style; in the second case, these are sites that have always operated on the internet to clarify doubts, and in the music field, those for solving technical or procedural problems relating to the use of digital tools are frequent.

The Weblog or the forum become a virtual learning environment when they are a place where a learning path takes place that relates the cultural background, the methodological choices, the disciplinary content, the project path, and the educational context [17] and supports the student in the perception and reconstruction of a project [18-19].

The web also provides the opportunity to access online platforms for music and elearning, platforms dedicated to specific areas of music theory: the most popular are GNU Solfege [20] (free learning environment) and EarMaster [21] (paid learning environment). They represent a stimulating, efficient and interactive educational tool: students see, hear, but above all they put music theory into practice. The weakness is represented by the fact that these platforms do not provide for the aspects of communication and interaction between peers [22-23]: the student performs exercises and receives feedback directly from the application through its Artificial Intelligence systems.

With the research presented in this article, a project was created to collect objective data on the effects of students' executive performance following the introduction of new technologies in musical learning at a theoretical level. For this reason, a learning environment has been designed paying attention to the necessary congruence between the different components of the context which explicitly and implicitly contributed to accompany the learning process.

Taking into consideration the characteristic aspects of the study of music, in the next paragraph we will try to deepen the concept of "learning environment", starting from the considerations highlighted in this paragraph and integrating them with an analysis of the student's cognitive styles.

\section{Design of the learning process}

\subsection{The learning environment}

The meaning that the expression "learning environment" assumes in practice is not always unique and often has an evocative value instead of a descriptive value of something specific, both in terms of concepts and practices.

The developments in the science of learning raise important questions about the design of learning environments: questions that suggest the value of rethinking what is taught, how it is taught, and how it is assessed [8][16].

The expression "learning environment" refers to the overall organization of the spaces, not only physical but also virtual, in which learning takes place. It is an organ- 
ization that should be functional, enjoyable and friendly [24]. To be functional, the organization of the spaces must meet the methodological and cultural premises and the learning objectives, making the most of the specific characteristics of the tools used [25-26]. To be enjoyable, it must take into account the reactions and preferences of the learners, favoring their involvement and motivation [8][27-28]. To be friendly, he must take into account pre-existing habits and skills, preferring simple solutions to unnecessarily complicated ones and also taking into account the emotional component (and not just the rational one) of the learning processes [26].

Properly selected hardware and software tools are also part of the learning environment in order to make it welcoming and stimulating for all the students involved, even for those with cognitive difficulties [29].

From what has been said above it emerges that the concept of a learning environment is in a necessary and immediate relationship with the student: the student's performance increases if he/she is put in the conditions to have an experience according to an acquisition mode organized around the person, to his/her expectations and motivations.

The learning environment, therefore, plays a strategic role in the learning process:

- it must give the student the opportunity to elaborate and re-elaborate the personal cognitive map in an active and constructive process;

- it must stimulate different learning processes in the mind of the student, through certain activities;

- it must encourage each student to relate the new knowledge offered by the teacher with the natural knowledge he already possesses, making the first one more understandable and interesting in relation to the second one;

- it must promote not only cognitive activities, but also metacognitive ones (reflexions and control with respect to one's own learning processes and products);

- it must be flexible and modular, careful to offer opportunities and options based on learning styles;

- it must intentionally promote processes of analogy and procedural knowledge (passing from examples and counter-examples, knowing how to do and knowing how to do it).

The design of the learning environment must therefore be done on the basis of the learning objectives.

\subsection{The operational formulation of learning objectives}

The planning of the learning process (with specific reference to the musical field) must be done through the formulation of the learning objectives which requires the use of specific descriptors, able to understand what is the performance required to the student in terms of cognitive processes activated and types of knowledge on which these processes operate.

For the development of the project described in this article, attention was paid to the thought processes that, in detail, interest the music student, referring to the classification proposed by L.W. Anderson and D.R. Krathwohl [21]. 
On the basis of this classification, the thought processes that refer to the following categories have been taken into consideration:

1. Remember: processes that refer to the recovery of knowledge from memory (Table $1)$;

2. Understand: processes that refer to the construction of meaning made by the student starting from data elements of information (Table 2);

3. Apply: processes that refer to the use of a procedure, theory or model to build a response to a given delivery (Table 3);

4. Analyze: which refer to the subdivision of a system into constituent parts and the identification of functional relationships between the parts themselves and between the parts and the entire system (Table 4).

Tables 1, 2, 3 and 4 were useful to define exactly what was expected from the student and to be able to direct the teaching efforts.

Table 1. Thought processes for the "Remembering" category

\begin{tabular}{|c|l|l|l|}
\hline Process & \multicolumn{1}{|c|}{ Synonymus } & \multicolumn{1}{|c|}{ Description } & \multicolumn{1}{c|}{ Examples } \\
\hline \multirow{3}{*}{ Recall } & $\begin{array}{l}\text { Cite a definition } \\
\text { - Rebuild a situation }\end{array}$ & $\begin{array}{l}\text { This process refers to remembering } \\
\text { or reproducing (solmizate) a melodic } \\
\text { / rhythmic segment on the basis of a } \\
\text { single stimulus (recall), or a struc- } \\
\text { tured set of stimuli (reconstruction). }\end{array}$ & $\begin{array}{l}\text { - What is the name of } \\
\text { this concept? } \\
\text { Break down the rhyth- } \\
\text { mic structure into a } \\
\text { simpler structure. }\end{array}$ \\
\hline \multirow{2}{*}{ Recognise } & $\begin{array}{l}\text { Find the corre- } \\
\text { sponding name } \\
\text { Identify within a } \\
\text { piece of music }\end{array}$ & $\begin{array}{l}\text { This process refers to finding the } \\
\text { object "already seen" within a piece } \\
\text { of music, or identifying the linguistic } \\
\text { term with which a concept has been } \\
\text { labeled. }\end{array}$ & $\begin{array}{l}\text { Look at this score. } \\
\text { Where is this concept } \\
\text { found? } \\
\text { From what elements } \\
\text { did you recognize it? }\end{array}$ \\
\hline
\end{tabular}

Table 2. Thought processes for the "Understanding" category

\begin{tabular}{|c|l|l|l|}
\hline Process & \multicolumn{1}{|c|}{ Synonymus } & \multicolumn{1}{|c|}{ Description } & \multicolumn{1}{c|}{ Examples } \\
\hline Interpret & $\begin{array}{l}\text { - Describe } \\
\text { Reformulate } \\
\text { Representing with } \\
\text { a different formal- } \\
\text { ism }\end{array}$ & $\begin{array}{l}\text { This process refers to describing a } \\
\text { concept in one's own words. }\end{array}$ & $\begin{array}{l}\text { - Describe this concept } \\
\text { in your own words. }\end{array}$ \\
\hline Exemplify & $\begin{array}{l}\text { Illustrate with } \\
\text { examples }\end{array}$ & $\begin{array}{l}\text { This process refers to finding exam- } \\
\text { ples of musical segments belonging } \\
\text { to a certain concept. }\end{array}$ & $\begin{array}{l}\text { - Transform this rhyth- } \\
\text { mic structure into a } \\
\text { rhythmically simpler } \\
\text { structure. }\end{array}$ \\
\hline Classify & $\begin{array}{l}\text { This process refers to inserting } \\
\text { rhythmic structures within catego- } \\
\text { ries fixed a priori on the basis of the } \\
\text { distinctive characteristics of the } \\
\text { objects belonging to the category. }\end{array}$ & $\begin{array}{l}\text { - Given the following } \\
\text { musical segments, } \\
\text { classify them in the } \\
\text { correct category among } \\
\text { those proposed. }\end{array}$ \\
\hline Compare & $\begin{array}{l}\text { Establish matches } \\
\text { (matching) } \\
\text { dighlighting } \\
\text { trasting) } \\
\text { Detect similarities } \\
\text { (map-ping). }\end{array}$ & $\begin{array}{l}\text { This process refers to identifying } \\
\text { similarities and differences or } \\
\text { correspondences between elements } \\
\text { and between organized sets of } \\
\text { elements (patterns) within two or } \\
\text { more musical phrases. }\end{array}$ & $\begin{array}{l}\text { Find all common } \\
\text { elements and / or dif- } \\
\text { ferences between these } \\
\text { musical phrases. } \\
\text { Identify the similarities } \\
\text { between these musical } \\
\text { phrases }\end{array}$ \\
\hline
\end{tabular}


Table 3. Thought processes for the "Apply" category

\begin{tabular}{|c|l|l|l|}
\hline Process & \multicolumn{1}{|c|}{ Synonymus } & \multicolumn{1}{|c|}{ Description } & \multicolumn{1}{c|}{ Examples } \\
\hline Carry out & $\begin{array}{l}\text { - Carry out a proce- } \\
\text { dure }\end{array}$ & $\begin{array}{l}\text { This process refers to the application } \\
\text { of a procedure (sequence of different } \\
\text { durations) for the correct rhythmic } \\
\text { interpretation of a musical segment. }\end{array}$ & $\begin{array}{l}\text { Perform the following } \\
\text { rhythmic structure. }\end{array}$ \\
\hline Implement & $\begin{array}{l}\text { - Use a theory or } \\
\text { model to build a } \\
\text { product. }\end{array}$ & $\begin{array}{l}\text { This process refers to using one or } \\
\text { more concepts to correctly interpret } \\
\text { a musical segment. }\end{array}$ & $\begin{array}{l}\text { - Build a rhythmic } \\
\text { structure based on the } \\
\text { elements you are given. }\end{array}$ \\
\hline
\end{tabular}

Table 4. Thought processes for the "Analyze" category

\begin{tabular}{|c|c|c|c|}
\hline Process & Synonymus & Description & Examples \\
\hline Differentiate & $\begin{array}{l}\text { - Decompose into } \\
\text { constituent parts } \\
\text { - To distinguish } \\
\text { - To focus } \\
\text { - To select }\end{array}$ & $\begin{array}{l}\text { This process refers to the } \\
\text { differentiation of the } \\
\text { constituent parts of a } \\
\text { rhythmic structure. }\end{array}$ & $\begin{array}{l}\text { - Identify the main and second- } \\
\text { ary elements in this rhythmic } \\
\text { structure. } \\
\text { - Examine the following rhyth- } \\
\text { mic structure and distinguish } \\
\text { the rhythmic accents. }\end{array}$ \\
\hline Organize & $\begin{array}{l}\text { - Find consistency } \\
\text { between elements } \\
\text { - Structuring } \\
\text { - Establish connec- } \\
\text { tions }\end{array}$ & $\begin{array}{l}\text { This process refers to the } \\
\text { identification of the role } \\
\text { that the various parts carry } \\
\text { out within a rhythmic } \\
\text { structure and the relation- } \\
\text { ships that are established } \\
\text { between them, determining } \\
\text { their execution. }\end{array}$ & $\begin{array}{l}\text { - Build a rhythmic structure } \\
\text { starting from the following data } \\
\text { elements: ... } \\
\text { - Use this model to build rhyth- } \\
\text { mic structure with reversal of } \\
\text { accents. } \\
\text { - Build a system of categories to } \\
\text { classify these structures. }\end{array}$ \\
\hline Confer & $\begin{array}{l}\text { - Identify commu- } \\
\text { nicative intentions }\end{array}$ & $\begin{array}{l}\text { This process refers to the } \\
\text { identification of communi- } \\
\text { cative intentions that help } \\
\text { interpret a piece of music. }\end{array}$ & $\begin{array}{l}\text { Describe what the following } \\
\text { rhythmic structures might de- } \\
\text { scribe: ... }\end{array}$ \\
\hline
\end{tabular}

Applying technologies to music teaching means developing in the user a flexibility of thought, a constructive curiosity, an openness to dialogue, an openness to novelty and diversity and, at the same time, a strong capacity for criticism and re-elaboration of information. It is therefore important to refer not only to a series of formal knowledge but also to practical experience.

\section{Application and analysis: a Case Study}

\subsection{Method}

This paragraph describes the pilot project realized in a Music High School on the basis of the considerations of the previous paragraphs: considerations that led to the creation of a Computer Supported Collaborative Music Learning (CSCML) environment.

The medium used for this "didactic challenge" was the Social Network.

Experience has highlighted the need for a solid design system, capable of allowing activities to take place in the intended direction, with the ability to monitor the process in real time and therefore to make changes where necessary. In any case, the 
project took shape and was enriched thanks to the shared knowledge and the creation of new knowledge resulting from their interactions.

The goals of the project were: on the one hand, to analyse the benefits of using ICT as a tool to support students in improving their skills on music theory and ear training; on the other hand, to analyse the improvement in the instrumental and vocal students' performances.

One of the main difficulties that the student encounters at the beginning of musical studies is the correct and conscious application of theoretical concepts (theory and solfège). Important considerations emerged from the analysis of a cognitive survey administered to students.

Theoretical concepts are studied because they are foreseen in the school curriculum and without giving them due importance. These concepts are accessory elements for the student and their study takes time away from studying the musical instrument. But it is precisely during the instrumental performance that the poor skills emerge: an incorrect reading of a rhythmic structure (solfège problems); an incorrect interpretation of the signs of musical agogic (problems in interpreting the signs of expression); in the case of studying a string or wind instrument, a poor ability to control intonation (ear training problems).

In many cases the student, following the teacher's advice, searches and listens to videos on YouTube and mechanically repeats a rhythmic passage playing at the same time to the performer of the video, until he thinks he is performing the piece correctly. As emerged from this research, when the student encounters an equal or similar passage in another piece of music, the initial rhythmic difficulties re-emerge. The same problem (if not even more serious) is that of listening to a piece and performing it the same without being aware of the agogic signs and making the performance sterile from any personal interpretative element.

Let's go back to paragraph 2 on the didactic use of video: to obtain more ambitious learning results, such as the ability to evaluate, re-elaborate and apply the acquired skills in a competent way, it is necessary to provide students with work tools capable of promoting analysis and reflection.

A similar conclusion can be provided in the case of using Ear-Training platforms (and solfège) where the student repeats a rhythmic structure mechanically following the beat proposed by the algorithm.

CSCML (as a learning environment) was designed with the aim of ensuring, supporting, and perfecting the possibilities for amplifying personal learning and the reflective and critical judgment skills of students. It integrated the use of different technologies, all however coordinated through the use of the Social Network. WhatsApp and Instagram were used as communication and social interaction platforms, and a series of open-source software (available for all operating systems) for the creation of educational resources: Musescore (music writing editor) [...], OpenShot (for making videos) [...], Audacity (for recording audio tracks) [...].

CSCML wanted to open a particular space capable of stimulating, provoking and supporting the personal interests and attitudes of each student, guaranteeing everyone's involvement, pleasure, self-confidence and the ability to express oneself. 


\subsection{Participants}

Initially, a survey (see Table 5) was distributed to all students of the first and second class of the music high school, for a total of 51 students ( 34 girls and 17 boys). The selection criteria for the students included:

- availability of the student in taking part in the project;

- musical instrument played by the student;

- experience of the student in playing with musical ensembles;

- "affective-motivational" relationship of the student with the technologies.

On the initial 51 students, 13 were selected to take part in project: 4 violin students, 2 cello students, 2 piano students, 2 flute students, 1 clarinet student, 1 percussion student and 1 guitar student.

The participants were selected through a purposive sampling technique. The selection was done to ensure that the students were able to use technologies in ways that were aligned with the fundamental purposes of the project, describe and share their experiences in an "articulate, expressive, and reflective manner", and that they were willing to participate in the research.

Table 5. Excerpt of the qualitative survey questions.

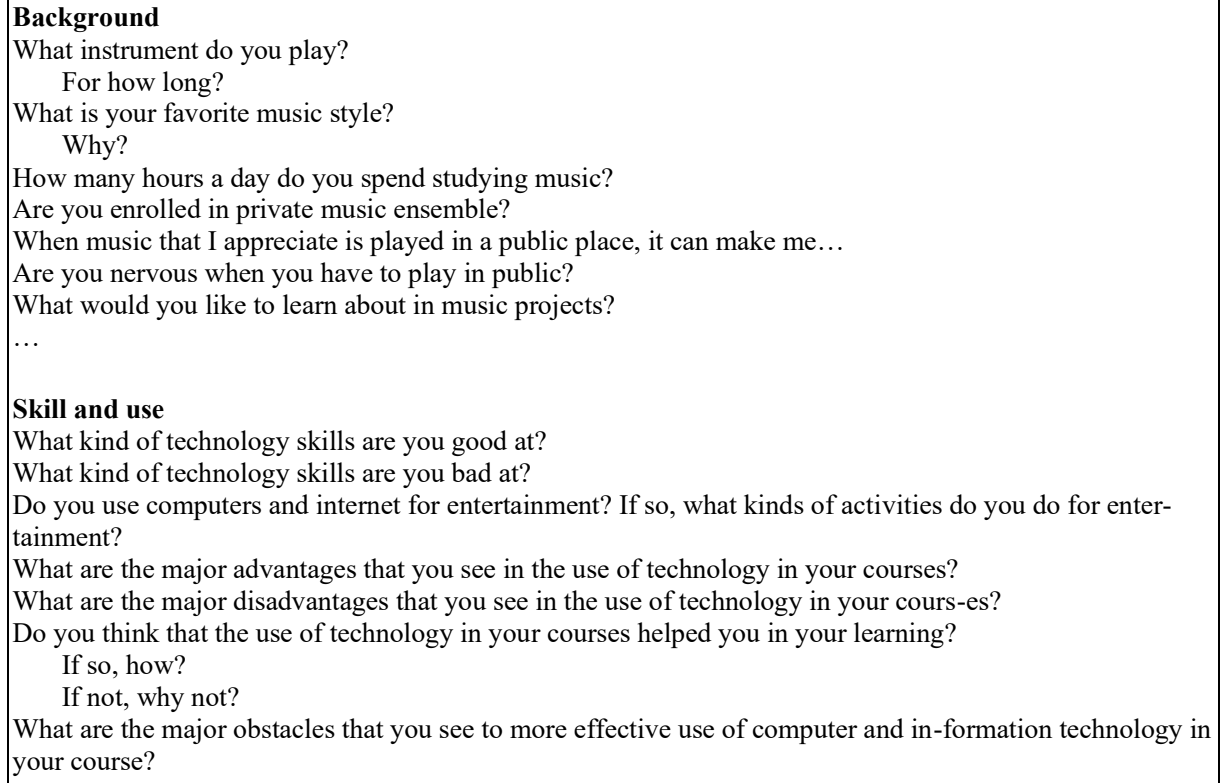

The project involved 7 teachers of musical instruments, 1 teacher of music technology and 2 teachers of theory and solfege 


\subsection{Methodology}

The project was conducted for a time period of 20 weeks, from January 2019 to May 2019, and it included the following activities:

1. individual instrument lesson (1 hour per week),

2. chamber music lesson ( 2 hours per week),

3 . theory and solfege laboratory ( 1 hour in the classroom and 2 hours online per week),

4. music technology laboratory ( 2 hours in the classroom and 2 hours online per week).

Before the start of the lessons foreseen by the project, the instrument teachers gave each student the score of a piece of music in which there were different rhythmic structures (with regular and irregular groups) and particular signs of agogic. Two private groups have been created respectively one on WhatsApp and one on Instagram to create an inclusive experience for all students. In particular:

WhatsApp has been set up to allow:

- quick communication between all group members (students and teachers);

- requesting help and support in solving a problem;

- sharing information (from a greeting message to troubleshooting tips) in different formats: text, image, audio and video

- sharing experiences and moods;

Instagram has been set up to allow:

- the creation of a shared database, containing all the material (text, images, video and audio) that was useful for the solution of the problems encountered and treated on the WhatsApp group and produced during the lessons in presence (for example recordings audio / video or new examples of scores with particular rhythmic structures);

- the possibility to insert hashtags to give value and meaning to a post facilitated the retrieval and consultation of the contents relating to a specific "topic"; the possibility to upload a maximum of ten photos / videos in a single post, which could be viewed as a slideshow, helped students to study.

During the first instrument lesson (first week of the project), each teacher, after having listened to the performance of the student, marked the errors (rhythmic and agogic) made by the student on a special form: this is allowed to teachers of theory and solfège to prepare a series of exercises of progressive difficulty to be administered to the students during the whole project.

In the following weeks (week 2 and 3 - 8 hours of lessons), the students attended exclusively the music technology laboratory, where the teacher explained the use of music word processing software (Musescore) and video editing (OpenShot) to allow each student to: 
- to be able to autonomously transcribe a rhythmic structure that was difficult to perform;

- be able to create a simple video to explain to other students how to perform a certain rhythmic structure.

From the fourth week, students were involved in all parallel activities (individual instrument lesson, chamber music lesson, theory and solfege laboratory and music technology) and also actively participating in social interaction on Social Networks. This activity proved to be stimulating for the students: the students responded to requests for help from their classmates, proposing in addition to a solution (audio files were more frequent than video files), also similar examples (images of rhythmic structures transcribed with MuseScore) encountered while studying their own repertoire (different from instrument to instrument). Teachers, in this phase, were only observers and intervened to make suggestions regarding the examples that were provided.

Each week the teachers had to mark on a special form, the rhythmic structures that were performed inaccurately by the students and the rhythmic structures that were instead performed correctly even if they had never been dealt with in class but had been the subject of solution on Social Networks. The students, in fact, had the task of updating the database on Instagram (through new posts) with the material that had been produced for the solution of individual problems and therefore could consult the database in case of need.

To consolidate the skills acquired in the individual study of the instrument, the students also attended the Chamber Music workshop, where it was important but also more difficult to correctly perform a piece of music as the simultaneous performance with all the other instruments could lead to error (in this regard it is important to remember that a group performance requires both attention to one's own score and attention to the contemporary performances of the other instrumentalists).

\subsection{Results}

At the end of the project one of the most interesting things that emerged refers to the increase of the number of rhythmical structures studied by students and played correctly. There was a substantial improvement in the execution of all students who expressed a positive opinion about the project.

Students said that they used technology firstly for the group activities and secondly for they personal interests and communication. They said that technology helped them to obtain prompt feedback by the group members, and collaborate and communicate with the group members. In their opinion technology provided them more opportunities for practice and reinforcement helped them better understand complex or abstract rhythmic structures. Finally, the project met their expectations.

The experience was also positive for the teachers who declared that it was a difficult job especially at the beginning of the project, having little confidence in the use of technologies, but then it became pleasant and useful because it helped them to know better the learning styles of individual students. 


\section{$5 \quad$ Discussion and conclusions}

Goals and expectations for musical education have changed during the past 10 years. ICT has become an integral part and an important tool in design the learning process both for increasing access to knowledge and as a means for promoting learning.

Technologies are creating new learning environments for music as well, which need to be carefully evaluated, including how their use can facilitate learning and the types of assistance the teacher needs to introduce these tools in the learning process.

But, to what extent do technologies help students learn music theory concepts with understanding rather than promoting the acquisition of disconnected sets of concepts and skills?

From this research it emerged that the learning environment is effective if it helps students to develop the thinking skills necessary to promote conceptual change: starting from an example, the student was able to gradually connect it to related situations which were less intuitive but involved the same theoretical principles. The teacher, therefore, must focus on understanding rather than memorization, involving students in activities that help them reflect on their learning and understanding. The greatest potential of technologies is versatility: in fact, it is only up to the creativity of teachers to find new ways of using technologies to improve learning.

With this project, digital technologies have not limited themselves to enhancing and improving traditional music teaching / learning strategies, but have also brought about completely new methodological experiences that have made it possible to integrate the dimension of doing with the dimension of understanding.

\section{References}

[1] Barron, B.J., Schwartz, D.L., Vye, N.J., Moore, A., Petrosino, A., Zech, L., Bransford, J.D., Cognition and Technology Group at Vanderbilt (1998). Doing with understanding: Lessons from research on problem and project-based learning. Journal of Learning Sciences 7(3 and 4):271-312. https://doi.org/10.1080/10508406.1998.9672056

[2] Bereiter, C., Scardamalia, M. (1993). Surpassing Ourselves: An Inquiry into the Nature and Implications of Expertise. Chicago and La Salle, IL: Open Court Publishing.

[3] Schwartz, D.L., Lin, X., Brophy, S., Bransford, J.D. (1999). Toward the development of flexibly adaptive instructional designs. In Instructional Design Theories and Models: Volume II, pp. 183-213.

[4] Svetsky S., Moravcik O., Tanuska P., Markechova I. (2018). The Practical Experiences with Educational Software for Modelling Interactive Collaborative Teaching. In: Auer M., Guralnick D., Simonics I. (eds) Teaching and Learning in a Digital World. ICL 2017. Advances in Intelligent Systems and Computing, vol 715. Springer, Cham. https://doi.org/10. 1007/978-3-319-73210-7 5

[5] Goodman, P.S.: Technology Enhanced Learning: Opportunities for Change, 336 p. Lawrence Erlbaum Associates, Inc., USA (2001).

[6] Esteves M., Pereira A., Veiga N., Vasco R., Veiga A. (2018) The Use of New Learning Technologies in Higher Education Classroom: A Case Study. In: Auer M., Guralnick D., Simonics I. (eds) Teaching and Learning in a Digital World. ICL 2017. Advances in Intel- 
ligent Systems and Computing, vol 715. Springer, Cham. https://doi.org/10.1007/978-3319-73210-7 59

[7] Tambunan H. The Effectiveness of the Problem-Solving Strategy and the Scientific Approach to Students' Mathematical Capabilities in High Order Thinking Skills. INT ELECT J MATH ED. 2019; 14(2), 293-302. https://doi.org/10.29333/iejme/5715

[8] Della Ventura, M. (2019). Between Research and Action: The Generative Sense of Technology. In: Rønningsbakk L., Wu TT., Sandnes F., Huang YM. (eds) Innovative Technologies and Learning. ICITL 2019. Lecture Notes in Computer Science, vol 11937, pp. 754763. Springer, Cham (2019). https://doi.org/10.1007/978-3-030-35343-8

[9] Sweeney, T., West, D., Groessler, A., Haynie, A., Higgs, B. M., Macaulay, J., et al. (2017). Where's the transformation? Unlocking the potential of technology-enhanced assessment. TLI 5, 1-13. https://doi.org/10.20343/5.1.5

[10] Waldron, J. (2012). Conceptual frameworks, theoretical models and the role of YouTube: Investigating informal music learning and teaching in online music community. J. Music Technol. Educ. 4, 189-200. https://doi.org/10.1386/jmte.4.2-3.189_1

[11] Smart, T., and Green, L. (2017). "Informal learning and musical performance," in Musicians in the Making: Pathways to Creative Performance, eds J. Rink, H. Gaunt, and A. Williamon (Oxford: Oxford University Press), 108-125.

[12] Chintalapati, N., Daruri, V.S.K., (2017). Examining the use of YouTube as a Learning Resource in higher education: Scale development and validation of TAM model, \| Telemat. Informatics, vol. 34, no. 6, pp. 853-860, 2017. https://doi.org/10.1016/j.tele.2016.08.008

[13] Schacter, D.L., Szpunar, K.K. (2015). Enhancing attention and memory during videorecorded lectures. Sch Teach Learn Psychol. 2015; 1:60-71. https://doi.org/10.1037/ st10000011

[14] Burgess, J. (2006). Blogging to learn, learning to blog. In A. Bruns, \& J. Jacobs (Eds.),Usesof blogs(pp. 105-115). New York, NY: Peter Lang Publishing.

[15] Churchill, D. (2009). Educational applications of Web 2.0: Using blogs to support teachingand learning.British Journal of Educational Technology, 40(1), 179-183. https://doi.org 10.1111/j.1467-8535.2008.00865.x

[16] Della Ventura, M. (2020). Removing Digital Natives from Technological Illiteracy with the weblog. T.-C. Huang et al. (Eds.): ICITL 2020, LNCS 12555, pp. 1-12, 2020. https://doi.org/10.1007/978-3-030-63885-6 65

[17] Churchill, D. (2009). Educational applications of Web 2.0: Using blogs to support teachingand learning.British Journal of Educational Technology, 40(1), 179-183. https://doi. org/10.1111/j.1467-8535.2008.00865.x

[18] https://www.gnu.org/software/solfege/solfege.html

[19] Gomez Trigueros, I.M. (2019). Methodologies Gamified as Didactic Resources for Social Sciences. International Journal of Emerging Technologies in Learning (iJET), Vol. 14, no. 23, pp. 193-207, 2019. https://doi.org/10.3991/ijet.v14i23.10794

[20] https://www.earmaster.com/

[21] Anderson, L.W. (Ed.), Krathwohl, D.R. (Ed.), Airasian,P.W., Cruikshank, K.A., Mayer, R.E., Pintrich, P.R.,Raths, J., \& Wittrock, M.C. (2001). A taxonomy forlearning, teaching, and assessing: A revision ofBloom's Taxonomy of Educational Objectives (Com-plete edition). New York: Longman.

[22] Baker, R. S. (2016). Stupid tutoring systems, intelligent humans. International Journal of Artificial Intelligence in Education, 26(2), 600-614. https://doi.org/10.1007/s40593-0160105-0

[23] N. Humble, P. Mozelius. Artificial intelligence in education-a promise, a threat or a hype? European conference on the impact of artificial intelligence and robotics 2019 (ECIAIR 
2019), Academic Conferences and Publishing International Limited, Oxford, UK (2019), pp. 149-156.

[24] da Luz, Fredson Soares dos Reis. (2015). The Relationship between Teachers and Students in the Classroom: Communicative Language Teaching Approach and Cooperative Learning Strategy to Improve Learning. In BSU Master's Theses and Projects. Item 22.

[25] Jonassen, D.H, Land, S.M. (eds), 2012, Theoretical Foundations of Learning Environment, New York, Routlegde.

[26] Karthik, B. S. S., Chandrasekhar, B. B., David, R., \& Kumar, A. K. (2019). Identification of instructional design strategies for an effective e-learning experience. The Qualitative Report, 24(7), 1537-1555.

[27] Della Ventura, M. (2017). Creating Inspiring Learning Environments by means of Digital Technologies: A Case Study of the Effectiveness of WhatsApp in Music Education, EAI Endorsed Transactions on e- Learning (Journal), Vol. 4, pp. 1-9, July 2017. https://doi.org/ 10.4108/eai.26-7-2017.152906

[28] Mulders, M., Buchner, J., Kerres, M. (2020). A Framework for the Use of Immersive Virtual reality in Learning Environments. International Journal of Emerging Technologies in Learning (iJET), Vol. 15, no. 24, pp. 208-224, 2020. https://doi.org/10.3991/ijet. v15i24.16615

[29] Stavroulia, K. E., \& Lanitis, A. (2019). Enhancing reflection and empathy skills via using a virtual reality-based learning framework. International Journal of Emerging Technologies in Learning (iJET), 14(07), 18-36. https://doi.org/10.3991/ijet.v14i07.9946

\section{Author}

Michele Della Ventura, professor of Music Technology, is a learning expert, researcher and instructional designer. He is the author of several articles presented at many conferences and published in international science magazines and high school textbooks. He proofreads articles and is a member of scientific committees in International Conferences.

Article submitted 2021-05-26. Resubmitted 2021-07-04. Final acceptance 2021-07-07. Final version published as submitted by the author. 